\title{
A Geospatial Approach to Enhance Point of the Interest and Tourism Potential Centers in Parner Tehsil in Maharashtra, India
}

\author{
Vasudev S. Salunke ${ }^{1}$, Santosh J. Lagad ${ }^{2}$, Ravindra S. Bhagat ${ }^{3}$, Nanabhau S. Kudnar ${ }^{4}$ \\ ${ }^{1}$ Assistant Professor in Geography, K. J. Somaiya College, Kopargaon, Dist-Ahmednagar, Maharashtra, India \\ ${ }^{2}$ Assistant Professor in Geography, Dada Patil Mahavidyalya Karjat Dist. Ahmednagar Maharashtra, India \\ ${ }^{3}$ Assistant Professor in Geography, S. S. Dhamdhere Arts \& Commerce College, Talegaon Dhamdhere, Tal- \\ Shirur, Pune, Maharashtra, India
}

${ }^{4}$ Corresponding Author, Assistant Professor in Geography, C. J. Patel College Tirora, Dist- Gondia, Maharashtra, India

\begin{abstract}
Article Info
Volume 8 Issue 1

Page Number: 186-196

Publication Issue :

January-February-2021
\end{abstract}

\section{Article History}

Accepted : 05 Feb 2021

Published : 15 Feb 2021

\section{ABSTRACT}

This study aims to identify geographical points of interest and tourism potential in Parner tehsil of Ahmednagar District of Maharashtra and to highlight the attractive tourist destinations and religious places in the region. To the introduced exact situation and importance of many wonderful, useful distinctive places and geographical point of interest in Parner tehsil. This paper is descriptive in nature and qualitative study based on empirical observations. This study based on primary and secondary data. All natural geographical, historical and cultural tourist centers were visited during study period. Parner tehsil is enriched of geographical, historical, and cultural tourism aspects. Suitable maps were prepared with the help of QGIS and ARC MAP software's for the ease of tourists. Tourist attractions in the tehsil as is, natural beauty, potholes, caves, temples, ideal village, industries, festivals etc. Even though Nighoj potholes and Vadgaon Darya caves are famous geographical destinations but other places are neglected by tourism industry experts. This paper will also become much helpful for planner, tourists, historians, geographers and archeologists to access remote but well known destinations.

Keywords : Geospatial Approach, Tourism, Tourist Centers, Natural Resources.

\section{INTRODUCTION}

India is land of diversity in natural manmade concerns so it is known as Epitome of World. In India there is vide variety in bio diversity, diversity in culture, historical monuments, natural scenic beauty, Forts, forests, wildlife which attracts tourist wards our country from worldwide $(37,38,1,2)$. Recently tourism is becomes big economic industry. Likewise Parner Tehsil is largest tehsil in Ahmednagar District which is largest District in Maharashtra in regards of geographical area. Parner

Copyright : (C) the author(s), publisher and licensee Technoscience Academy. This is an open-access article distributed under the terms of the Creative Commons Attribution Non-Commercial License, which permits unrestricted noncommercial use, distribution, and reproduction in any medium, provided the original work is properly cited 
tehsil is located on Deccan plateau which give wide tourist destinations and geographical points of interest $(19,28)$. Parner taluka lies in rain shadow zone some highlands consists sparse forests, and vast grasslands becomes ideal habitat for wildlife. Besides this historical monuments, forts, temples, citadel Village and pandava caves, water bodies marvelous waterfalls becomes perfect background for tourism development in Parner taluka. This industry generates employment tax and revenue it produces ancillary industries. Considering these all aspects in mind an attempts has been made to study the potential of tourism development in taluka which is hilly and industrially backward (39, 35, 34, 36).

Tourism is one of the largest and fastest growing segment in world. These tourism sector providing largest employment. Tourism sector has play a major role in development process. Nowadays, India is having greater scope in tourism sector. This study is aimed to introduce exact situation and importance of many wonderful, useful distinctive places and geographical point of interest in Parner tehsil. This paper also emphasized the various geographical and religious aspects of developmental issues of the area. Parner tehsil is enriched of geographical, historical, and cultural tourism aspects $(3,4,12,13,14,29)$.

The object of study region is, to highlight the attractive tourist destinations and religious places in the region. This study based on primary and secondary data. Tourist attractions in the district as is, natural beauty, potholes, caves, temples, ideal village, industries, festivals etc. To the visit of tourist, which requires natural resources, infrastructural and transportation facilities, accommodation, food, recreation sightseeing, shopping and variety of facilities and services for use and enjoyments. The source of tourism depends on all these facilities.

\section{STUDY AREA}

The Parner taluka lies in Ahmednagar district consists of 131 villages and one urban centre.
Geographically extension of taluka between $18^{\circ} 49^{\prime} 40^{\prime}$ $\mathrm{N}$ to $19021^{\prime} 13^{\prime \prime} \mathrm{N}$ Latitude and 74 10' 22' E to $74^{\circ} 38^{\prime}$ 34" E Longitude (Fig. 1). Geographically, it located on Deccan plateau. The region is drained by river Kukadi, Ghod \& Sina. Sangamner tehsil lies in northwest, Rahuri tehsil lies in northeast, Nagar tehsil lies in east, Shrigonda tehsil lies in southern side \& Pune districts boundary belongs to western side of Parner tehsil. The geographical area of the study region is 1930.28 sq. $\mathrm{km}$ and has population 274167 according to 2011 census. Out of the total population 140267 are male and 133900 are female population and the density of the population is 142 per sq. Km. Parner tehsil lies in the rain shadow or rain fed zone of Maharashtra state. National highway, state highway, major district road, other district road and village road are major routes of transport in Parner tehsil (23, 24, 27, 26, 25).

\section{OBJECTIVES}

The main objectives of the study were as follows:

1) To study the geographical point of interest in Parner tehsil

2) To highlight tourist places in study region

3) To review the progress of tourism related works in the study region.

\section{DATA COLLECTION AND METHODOLOGY}

This study is based on investigation, information about various places were acquired from spot observations. The research work is based on the primary and secondary data. Primary data was collected from to visits the various tourist centers with help of photographs, interviews and questionnaire of tourist, pilgrims, stakeholders etc. Secondary data was collected from reference books, periodicals, booklets, daily newspapers, magazines, reports, internet etc. The report from forest department, Ahmednagar District Gazetteer and reports from tourism department etc $(31,32,33)$. 


\section{RESULT AND ANALYSIS}

\section{Tourist Attractions in the Parner Tehsil:}

Major tourist centers in the Parner tehsil are explained as follows-

\section{Geographical Landforms:}

Parner taluka is enriched by variety of geographical destinations which include world famous potholes in Kukadi river, The world famous potholes were present near Nighoj village. These potholes are called as Kund or Ranjankhalge in Marathi. Nighoj potholes are formed in Kukadi river bed. These series of potholes are formed in basaltic rocky channel are supposed to be the biggest in Asia continent. These potholes $90 \mathrm{~km}$ away from Pune district centre and $20 \mathrm{~km}$ away from Pune-Ahmednagar road. Nighoj potholes are observed on hard rocky stretch of $1.5 \mathrm{~km}$ which forms a boundary between Pune and Ahmednagar district. These potholes are formed by basalt rock of Kukadi river. The pothole length is two to three kilometer, width is ten meter and depth is twenty-five to fifty meter (Table 1).

In Parner tehsil area having the famous geological destinations. The famous geological attraction is stalactite and stalagmite in the caves of Padali Darya. Padali Darya located in Parner tehsil 24 kilometer away from northwest side of Parner city. This relief is carved by underground water work in rocks mainly composed by calcium carbonate. Calcium carbonate dissolved in underground water which resulted in to huge caves. In this caves development of stalactites, stalagmites taking place due to calcium depositions and saturation from sealing and ground. Stalactite are formed naturally after a longer process and the structures of calcium carbonate dolomite depositions. Stalactite and stalagmites joints together after long period and finally take shape of hard pillar. Stalagmite is formed due to continuous percolation of saline water from limestone at floor of caves. Both stalactites and stalagmites length increasing year by year. Padali darya cave, stalactites, stalagmites, several monkeys and dense vegetation in valley of these areas attraction of tourists.

Mula river flows on the border of Sangamner and Parner taluka. Mula is important tributary of Godavari river. Near village Mandave Kh. Mula river has flows through acute gorge. Hard basalt is cut by water drift and narrow gorge formed. Gorge is $30 \mathrm{mt}$ wide, $35 \mathrm{mt}$ in depth and approximately $300 \mathrm{mt}$ in length. Several small potholes are also observed in river bed $(22,21,17,18,20)$. This small gorge is not much famous. Maximum area of tehsil is occupies by plateau which is locally known as pathar so several villages are named as Pathar Viz. Nandur Pathar, Bhoyare Pathar Kanhur Pathar. Near Kanhur Pathar Dashabai peak is highest peak of Parner taluka with elevation of $899 \mathrm{mts}$.It works as interfluve between Krishna and Godavari river basin. On the hilltop Vitthal Temple and mosque are close to each other this is rare example of cultural tie between two communities. Near Dhavalpuri village there is series of flat top hills like Mesa and Butte.

\section{Water Bodies:}

Mandohol dam is small project and started in 1984.Mandohol dam is $5 \mathrm{~km}$ from village Karjule hareshwar on Ahmednagar -Kalyan Highway. Dam Wall is made with earthen $27 \mathrm{mt}$ in height and 739 $\mathrm{mt}$ in wide. Capacity of this dam is 399 million Sq.foot. (0.4 TMC).This dam is prolific for the drought-prone area of Parner Taluka. Nowadays this dam is being popular for its scenic beauty, water games and natural sightseeing. It becomes more thrilling and adventures because of valley and hill topography (Fig. 2).

Ruichonda Waterfall is another tourist destination nearly $1.2 \mathrm{~km}$ from Mandohol dam on same downstream. This water fall formed on Mandohol River $(15,16)$. Water falls from the cliff height of $25 \mathrm{mt}$ to gorge. Deep plunge pool formed in water (Fig 3). There is a temple of goddess Malganga several devotees from vicinity come here for worship. 
It is point of attraction for several adventures youth Visapur dam is also one point of attraction for tourist. Several Wild animals and migratory birds comes on dam. It is paradise for bird watcher (Fig. 4).

\section{Wild Life:}

Parner taluka is largest taluka in Ahmednagar district in respect of geographical area. It occupies 1930 sq. Km geographical area out of it 187.9 sq. K.m $(9.74 \%)$ area is under forest and grasslands. In recent years wildlife is flourished in large grasslands so such herbivores animals like deer, Palm civet, Monitor Lizard, antelopes, rabbits etc. Due to these prosperous animals life in grasslands carnivores animals like fox, wolfs, Jungle Cat, Leopards are increasing rapidly. In the northern region of tehsil extensive grassland and scattered forest in were observed in Wasunde, Khadakwadi, Vadgaon, Vankute ,Dhavalpuri, Dhoki belt which is good habitat for wildlife. Increasing wildlife make same encounters between Wildlife and humans $(9,10,11,5,6,7,8)$.

\section{Temples and Religious Sites:}

Malganga Temple Nighoj Goddess Malganga is situated near river. Both bank of kukadi river devotee people built a temples. The annually festival of goddess Malganga is celebrated in month of March or April. In the annual fair of goddess Malganga earthen pot appear in well is the main attraction of devotees. Many pilgrims visited in festival to pothole. School-college students, researchers, stakeholders visited in whole year (Fig. 5).

God Khandoba of Pimpalgaon Rotha famous family god of vicinity. God Khandoba temple. Yearly five days festival Yatra is celebrated in the month of March. In every annual fair five to seven lakh devotees visited Pimpalgaon Rotha.

\section{Sant Nilobarai Samadhi Temple form} Pimplaner is an important pilgrimage for Warkari sampraday. Sant Nilobarai were Student of Sant Tukaram Maharaj. Religious attachment of vaishnav society and peoples are main attraction of several sant and manhants. Bhairavnath Temple of Punewadi,
Hangeshwar Temple of Hanga, Sidhheshwar temple of Sidhheshwarwadi, Dhokeshwar Temple of Takali dhokeshwar, Vithhal Rukhmini Temple of Palshi, are some secred place in Parner taluka.

\section{Historical forts:}

Parner Taluka has great references from mythological period therefore taluka name after sage Parashar who is father of Maharishi Vedvyas. Several villages have Pre historical and historical background and historical relations since time of Chatrapati Shivaji Maharaj and Peshava period. Jamgaon, Kanhur Pathar, Palashi are very well known examples of this. Hanga Village near Parner has historical background from $16^{\text {th }}$ century. Head of Chatrapati Shivaji maharaj was Bahirjee Naik was from Hanga village.There are some historical evidences are available of the same. Jamgaon Fortress or Wada is monument is contemporary of great Panipat battle of Maratha. This Wada was built by great Maratha Sardar Mahadaji Shinde. Dabhade Wada is faomous in parner. Jahagirdar wada is famous in Kanhur. Another point of attraction for historians is Fortress of Palshi which has citadel and gate compact even today. Parner is birthplace and work place of Senapati Bapat great Indian leader and freedom fighter.

\section{Architectural Style and Caves:}

Historical Dhokeshwar cave located in Dhoki village. This cave are curved during carvation period of Ajanta and Ellora caves. This Caves are tourism places under archeological survey of India. This site has religious importance because holy temple of lord Shiva is located. Annual Fair has been started at third shravan Monday. Thousands of people visit to this place in a year with religious and architectural aspects.

Another architectural attraction of Parner Taluka is Vithhal Rukhmini Temple located at Palashi Village. Village is $15 \mathrm{~km}$ northwards from Takali Dhokeshwar. On the bank of small river temple has by carved by so many sculpture. Temple is 
built in $17^{\text {th }}$ century and locals are relate this temple with legendary second robbery of Surat by Chatrapati Shivaji Maharaj. Stone pillars are carved in shape of lotus, Garuda and Hanuman. Second floor of temple is carved in wooden arts. Also in Parner tehsil Pimpalner, Valavane, Jamgaon, Kanhur pathar, Palshi, Alkuti, siddheshwarwadi villages are with various angle attraction of tourists (40).

\section{Ralegan Siddhi : Model Village for Water Conservation:}

Ralegan Siddhi is famous for ideal village and well-known personality of Padmvibhushan Hon. Anna Hajare. Under the guidance of Hon. Anna Hajare villagers developed these village drastically. Now a days this village play a role model of ideal village. Management and conservation of water, forest, soil, animal etc. attraction of visitors. Water

conservation work and water shade management are the main keys of Ralegan siddhi village. Therefore several social workers, tourists, gram panchayat members and workers visits this village throughout the year. Different projects and programs was organized in village. Rural development training center famous in India. All over India and out of Indian peoples are visit to Ralegan Siddhi.

Recently Shahanjapur -Supa village and its surrounding area famous for industry and windmill. Several industries from Japan has been arrived in Supa MIDC. Near supa village on the hilly region established more than fifty windmills. This project run by Suzlon India ltd. This emerging energy park is becoming new destination for tourist in taluka (31, 32, 33).

Table 1. Types of Tourist Destinations

\begin{tabular}{|c|c|c|c|c|}
\hline $\begin{array}{l}\text { Sr.N } \\
\text { o. }\end{array}$ & $\begin{array}{l}\text { Cate } \\
\text { gory }\end{array}$ & Criteria & Landforms/Resources & Tourist Places \\
\hline 1 & : & $\begin{array}{l}\text { Geographical } \\
\text { Landforms }\end{array}$ & $\begin{array}{l}\text { Potholes, stalactite and stalagmite, } \\
\text { Table land, George, Mesa \& Butte, } \\
\text { Dashabai Peak. }\end{array}$ & $\begin{array}{l}\text { Nighoj, Vadgaon Darya, } \\
\text { Mandva, Dhavalpuri, } \\
\text { Kanhur Pathar }\end{array}$ \\
\hline 2 & 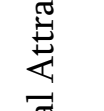 & Water bodies & $\begin{array}{l}\text { Mandohol Dam, Ruichonda fall, } \\
\text { Visapur Dam, George in Mula river }\end{array}$ & $\begin{array}{l}\text { Karjule Hareshwar, } \\
\text { Mandava Kh, }\end{array}$ \\
\hline 3 & 䒿 & Wildlife & $\begin{array}{lll}\text { Vadgaon Savatal -Vankute Forest } \\
\text { Region }\end{array}$ & $\begin{array}{l}\text { Vadgaon } \quad \text { Wasunde } \\
\text { Vankute }\end{array}$ \\
\hline 4 & \multirow{4}{*}{ 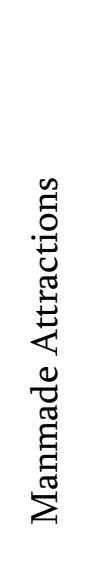 } & Religious & $\begin{array}{l}\text { Malganga Temple, Daryabai Temple, } \\
\text { Khandeshwar Temple, Bhairavnath } \\
\text { Temple, Dhokeshwar Temple }\end{array}$ & $\begin{array}{ll}\text { Nighoj, Vadgaon } & \text { Darya, } \\
\text { Pimplagaon } & \text { Rotha, } \\
\text { Punewadi, Takali } & \end{array}$ \\
\hline 5 & & $\begin{array}{l}\text { Historical } \\
\text { forts }\end{array}$ & $\begin{array}{l}\text { Mahadaji Shinde Wada } \\
\text { Palshi Fortified Village } \\
\text { Village of Bahirji Naik }\end{array}$ & $\begin{array}{l}\text { Jamgaon, Hanga,Parner } \\
\text { Palshi, Kanhur Pathar }\end{array}$ \\
\hline 6 & & $\begin{array}{l}\text { Arch. Style } \\
\text { Caves }\end{array}$ & $\begin{array}{l}\text { Dhokeshwar Caves, Vithhal Rukhmini } \\
\text { Temple, }\end{array}$ & Takali Dhokeshwar, Palshi \\
\hline 7 & & $\begin{array}{l}\text { Roll Model } \\
\text { Village }\end{array}$ & $\begin{array}{l}\text { Water shade Management and } \\
\text { Forest, Water Conservation }\end{array}$ & Ralegan Siddhi \\
\hline
\end{tabular}




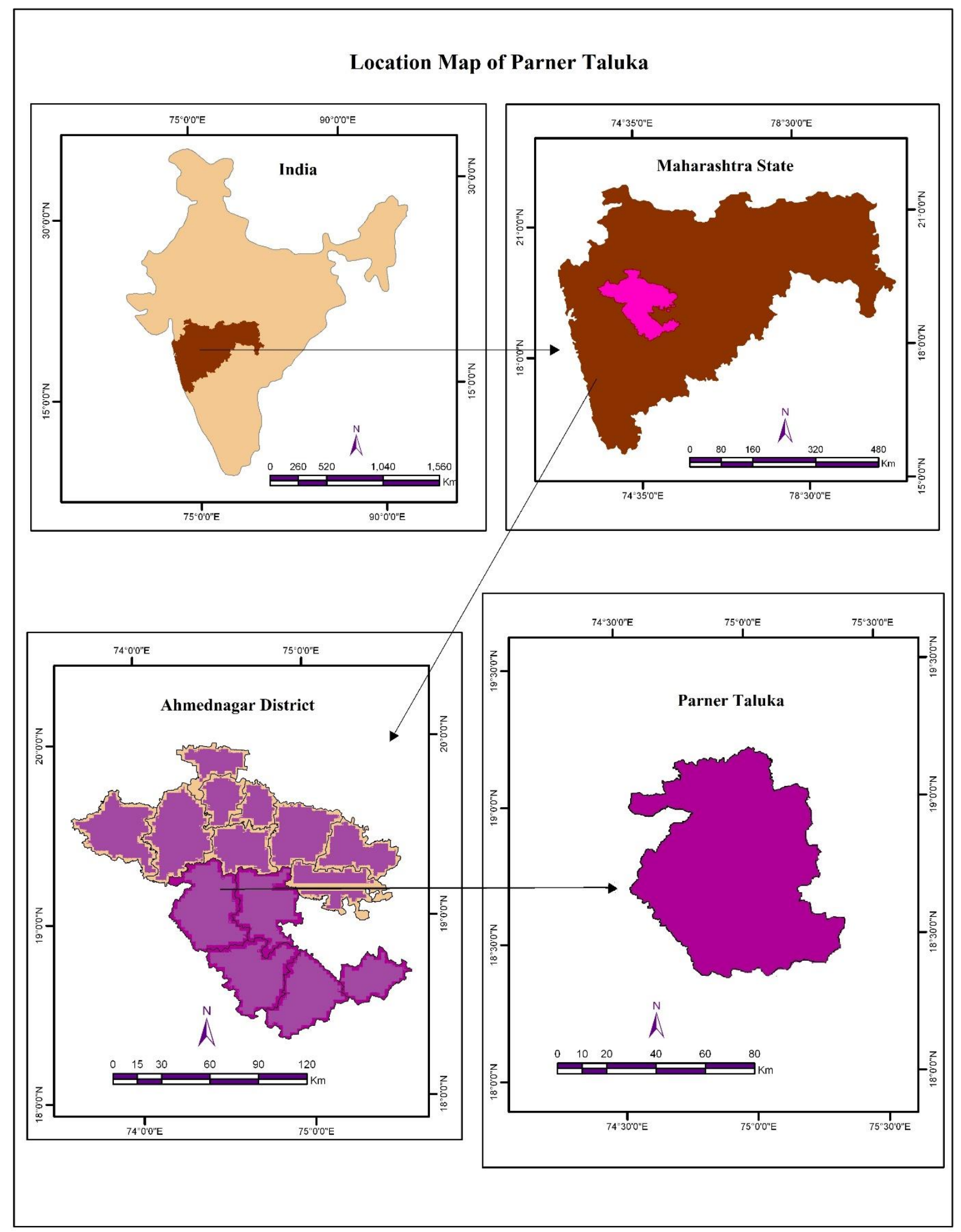

Fig. 1. Study Area. 


\section{Parner Tourist Place Map}

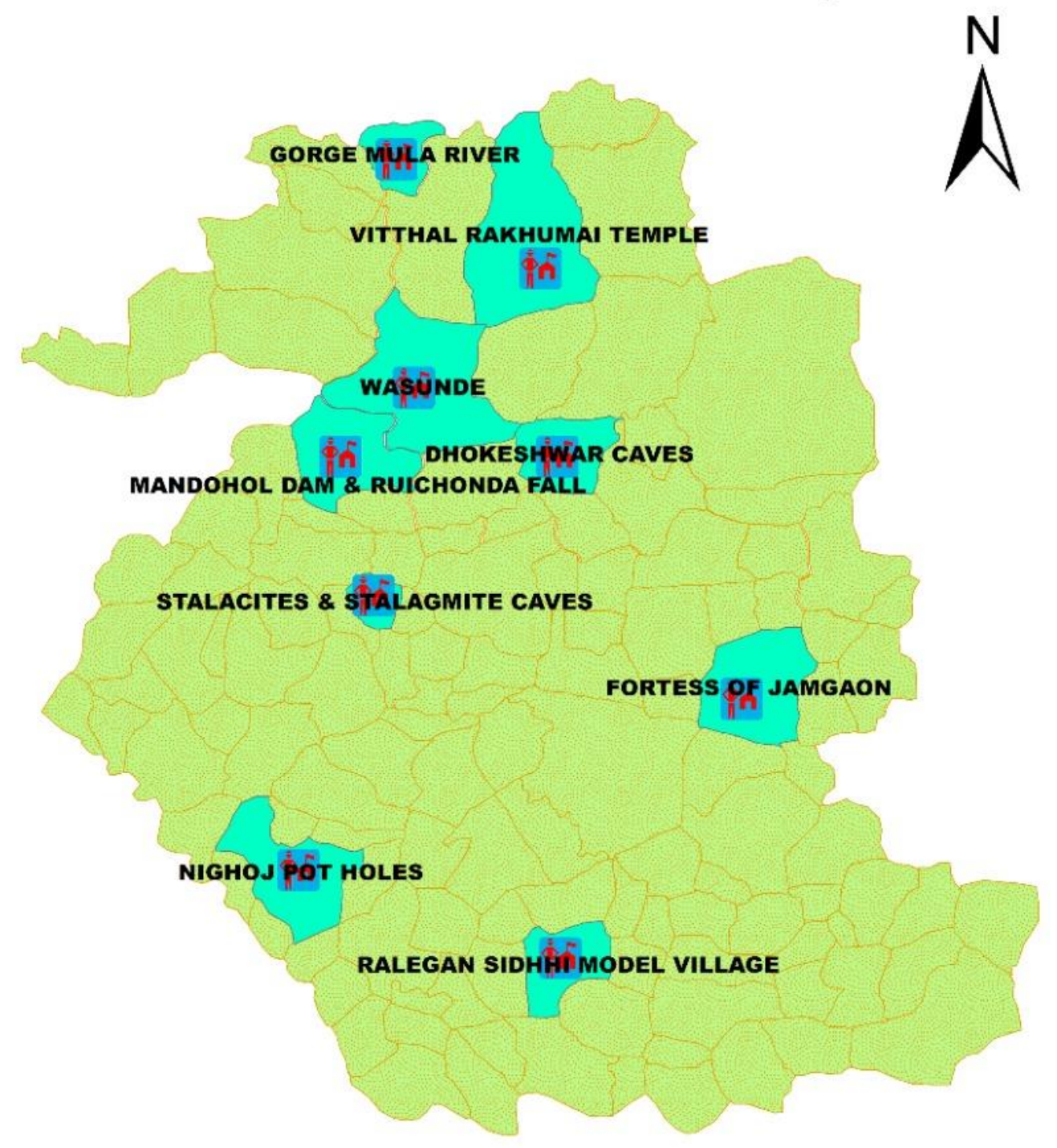

\section{Legend}

\section{- Tourist Places $\quad \begin{array}{llllll}0 & 5 & 10 & 20 \text { Kilometers }\end{array}$}

Fig. 2. Tourist Places 


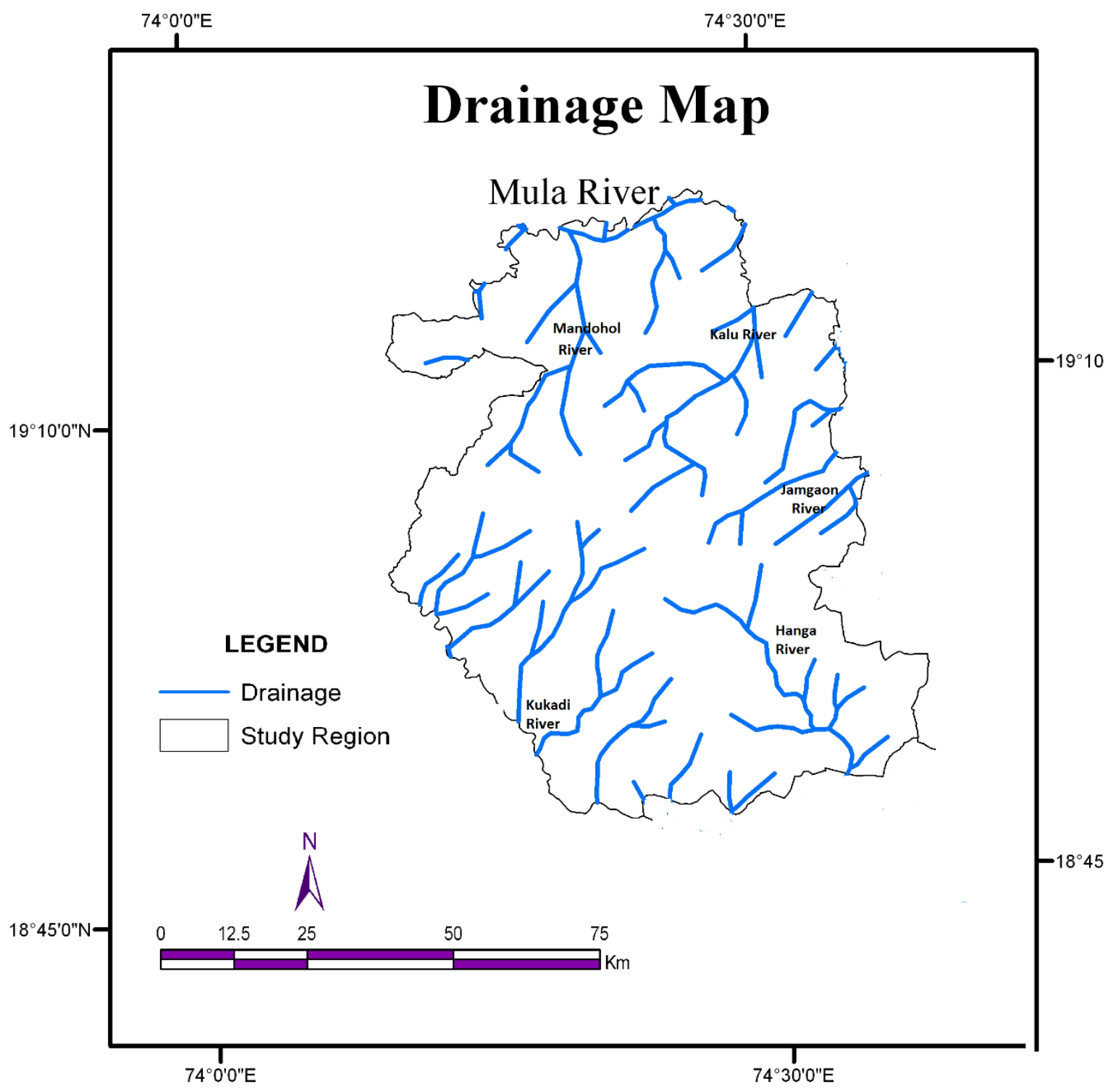

Fig. 3. Drainage Map. 


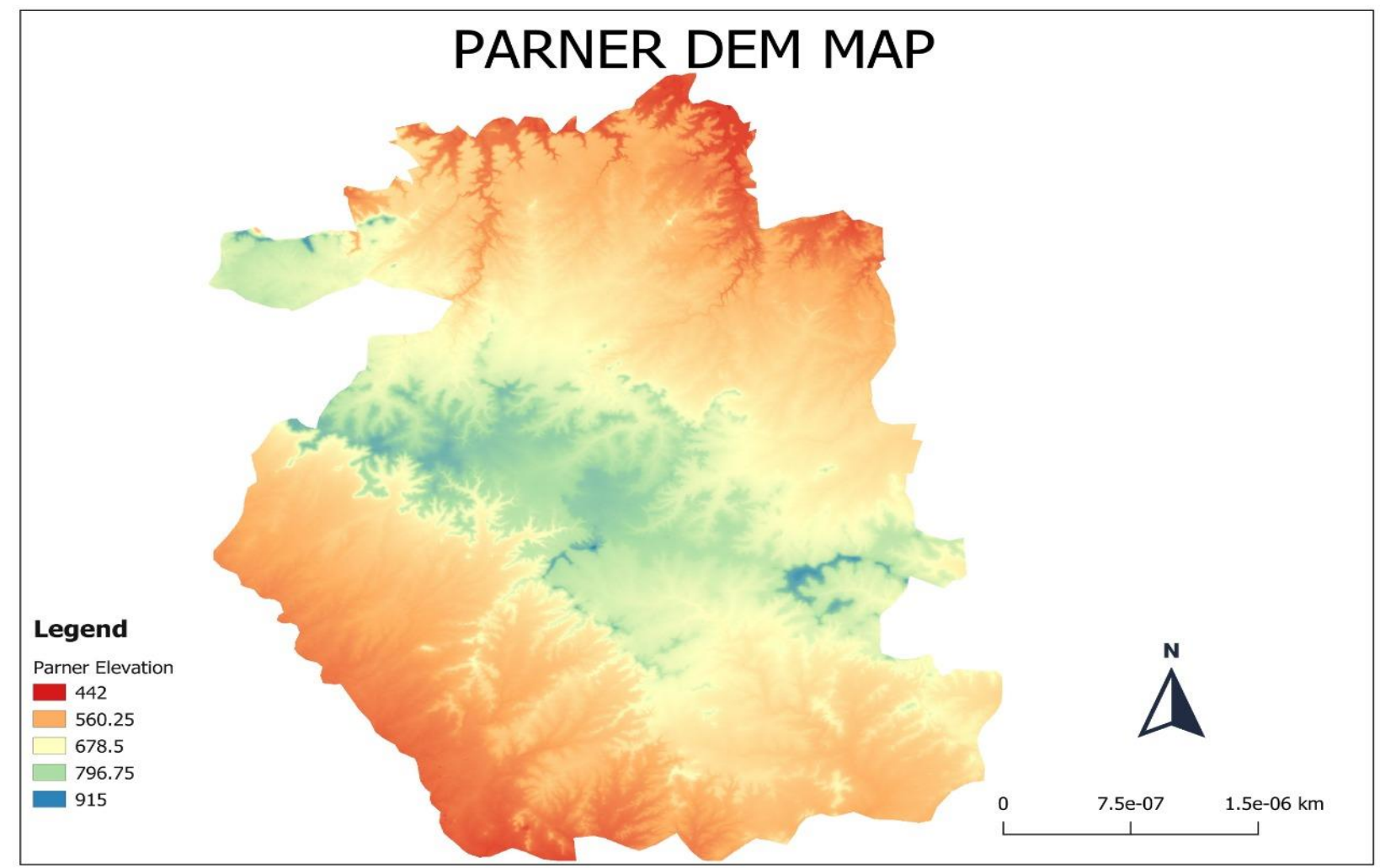

Fig. 4 Digital Elevation Model

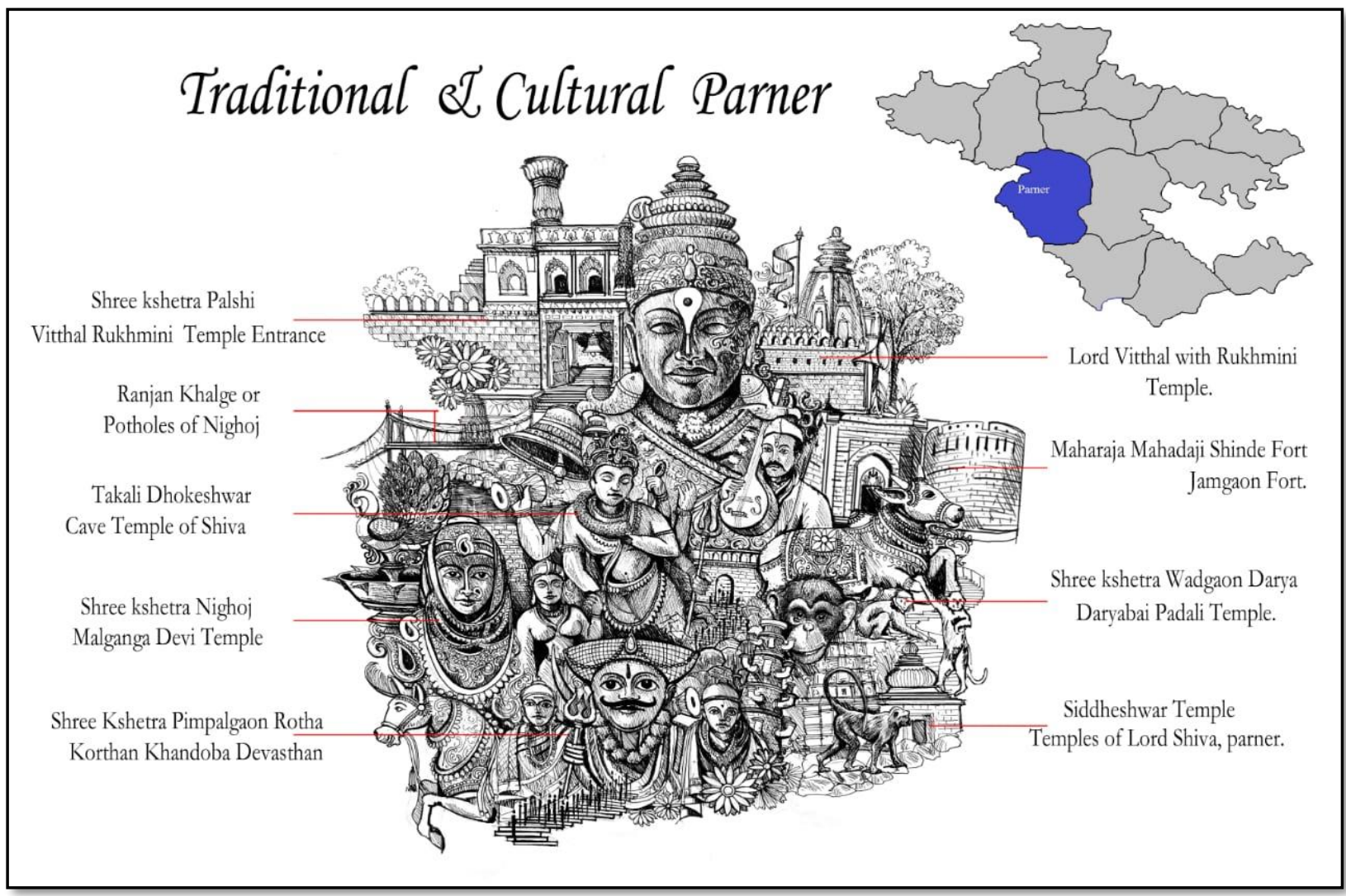

Fig. 5. Traditional and Cultural Places 


\section{CONCLUSION}

Tourism in the tehsil can be well developed in Parner tehsil with proper planning. The development of tourism center are provide employment to thousands of local people. Tourist affects potholes at Nighoj so it needs to be cherished as it is a specific phenomenon. Government will take action and control on construction in Nighoj pothole area. In Parner tehsil huge scope to obtain wind energy in hilly ranges area which will uplift the economic status of the people. At Nighoj pothole and Padali darya cave affected by human traditions. To the visit of tourist at tourist center which requires natural re-sources, infrastructural and transportation facilities, accommodation, recreation, sightseeing, shopping and variety of facilities and services for use and enjoyments. The success of tourism de-pends on all these facilities. The tourism activity generates employment opportunities in various part of study region.

\section{VI.ACKNOWLEDGEMENT}

Researcher is very much thankful to Artist and Designer Mr. Pradip Wackchaure (Wasunde, Parner) for his notable contribution as digital painting of Parner Taluka tourist places in shape of taluka map.

\section{VII.REFERENCES}

[1]. Agarwal, S. (1999) Restructuring and local economic development: Implications for seaside resort regeneration in Southwest Britain. Tourism Management, 20, 511-522.

[2] . Aminu, M., Matori, A.N., Yusof, K.W. et al. (2017) Analytic network process (ANP)-based spatial decision support system (SDSS) for sustainable tourism planning in Cameron Highlands, Malaysia. Arab J Geosci 10, 286. https://doi.org/10.1007/s12517-017-3067-0
[3]. Bahaire T, Elliott-White M (1999) The application of geographical information systems (GIS) in sustainable tourism planning: a review. J Sustain Tour 7(2):159-174

[4]. Bessiere, J. (1998) Local development and Heritage: Traditional food and cuisine as tourist attractions in rural areas. Sociologia Ruralis, 38(1), 21-34.

[5]. Bhagat R. S. (2020) Longitudinal Dispersion Characteristics of Wainganga River and Natural Streams, India, Our Heritage 68 (1), 884-892.

[6] . Bhagat R. S. (2020) GIS-Based Assessment Of Physiographic And Hydrological Parameters Of Wainganga Sub Basin, Maharashtra, India. Shodh Sarita 7 (27), 14-21.

[7]. Bhagat, Ravindra and Bisen Devendra (2015) Flood Study of Wainganga River in Maharashtra Using GIS \& Remote Sensing Techniques, International Journal of Science and Research, 782-785.

[8]. Bhagat, Ravindra and Bisen Devendra (2016) Land use and Land cover of Wainganga River in Maharashtra using GIS and Remote sensing technique, Golden Research Thoughts, International Recognition Multidisciplinary Research Journal ISSN: 2231-5063, Volume - 5 | Issue - 9, Page No. 1-7

[9]. Bisen D. K. (2020) Traditional Water Management Systems of Gondia District: Community Conservation, Thematics Journal of Geography, Vol-8-Issue, 354-363.

[10]. Bisen D.K and Kudnar N.S. (2013) A Sustainable Use and Management of Water Resource of the Wainganga River Basin: - A Traditional Management Systems. figshare. Journal contribution. https: //doi.org /10.6084 /m9. figshare. 663573.v1

[11] . Bisen D.K and Kudnar N.S. (2019) Climatology, Sai Jyoti Publication, Nagpur.pp-11-211.

[12]. Chew J, (1987) Transport and tourism in the year 2000. Tourism Management, 8(2): 83-85. 
[13] . Ferreira, S. (2007) Role of Tourism and Place Identity in the Development of Small Towns in the Western Cape, South Africa. Urban Forum 18, 191-209. https://doi.org/10.1007/s12132007-9011-8

[14]. Kan, Ak., Li, Gq., Yang, X. et al. (2018) Ecological vulnerability analysis of Tibetan towns with tourism-based economy: a case study of the Bayi District. J. Mt. Sci. 15, 11011114. https://doi.org/10.1007/s11629-017-4789$\mathrm{X}$

[15] . Kudnar N. S. (2016) "Topographic Characteristics of the Wainganga River Basins Using GIS \& Remote Sensing Techniques" Multidisciplinary Research Journal, Indian Streams Research Journal, 5- pp 1-9.

[16] . Kudnar N. S., (2018) Water Pollution a Major Issue in Urban Areas: A Case Study of the Wainganga River Basin". Vidyawarta International Multidisciplinary Research Journal pp 78-84.

[17] . Kudnar N.S., (2017) Morphometric Analysis of the Wainganga River Basin Using Traditional \& GIS Technique, Ph.D. Thesis, Rashtrasant Tukadoji Maharaj Nagpur University, Nagpur, Pp 66-250.

[18] . Kudnar, N. S., (2015) Linear Aspects of the Wainganga River Basin Morphometry Using Geographical Information System Review Of Research 5 (2), 1-9

[19] . Kudnar, N.S, (2019) Impacts of GPS-based mobile application for tourism: A case study of Gondia district, Vidyawarta Int Multidiscip Res J 1:19-22.

[20] . Kudnar, N.S. and Rajasekhar, M, (2020) A study of the morphometric analysis and cycle of erosion in Waingangā Basin, India, Modeling Earth Systems and Environment 6 (1), 311-327, (2020). https://doi.org/10.1007/s40808-01900680-1

[21] . Kudnar, N.S., (2020) GIS-based assessment of morphological and hydrological parameters of
Wainganga river basin, Central India. Model. Earth Syst. Environ. 6, 1933-1950. https://doi.org/10.1007/s40808-020-00804-y

[22] . Kudnar, N. S., Padole, M. S, et al (2021) "Traditional crop diversity and its conservation on-farm for sustainable agricultural production in Bhandara District, India", International Journal of Scientific Research in Science, Engineering and Technology (IJSRSET), Online ISSN : 2394-4099, Print ISSN : 2395-1990, Volume 8 Issue 1, pp. 35-43, January-February 2021. Available at doi https://doi.org/10.32628/IJSRSET207650 Journal URL : http://ijsrset.com/IJSRSET207650

[23] . Lagad S. J. (2020) Physiographic Analysis of the Hivare Bazar Village Using GIS and RS Techniques, Studies in Indian Place Names 40 (3), 5528-5536.

[24]. Lagad S. J. (2018) Demographic Development Pre and Post Watershed Development of Model Watershed Village Hivrebazar in Nagar Tahesil, International Journal of Research in Social Sciences 8 (12), 353-365.

[25] . Lagad S. J. (2019) Demographic Development Pre and Post Watershed Development of Model Watershed Village Ralegansiddhi in Parner Tahesil. Maharashtra Bhugolshastra Sanshodhan Patrika 36 (1), 37-48.

[26] . Lagad S. J. (2017) Role of Water Conservation in Rural Development- A Case Study of Model Villages in South Ahmednagar District. Rashtrasant Tukadoji Maharaj Nagpur University, Nagpur. pp-22-300.

[27]. Lagad S.J. and Kamble D. B.(2020) GeoPolitical Dispute Between India and China and Its Impact on Bilateral Trade, Studies in Indian Place Names 40 (60), 2215-2227

[28]. Leiper N, (1990) Tourist attraction systems. Annals of Tourism Research, 17(4): 33-45.

[29]. Saha, K., Kalra, R. \& Khare, R. (2020) A geospatial approach to enhance religious tourism in India-A case of Ujjain city, 
Madhya Pradesh. GeoJournal. https://doi.org/10.1007/s10708-020-10334-w

[30]. Salunke V. S. (2019) Study of urbanization Trends in Western Maharashtra, Maharashtra Bhugolshastra Sanshodhan patrika, 36-2, pp 6771.

[31]. Salunke V. S. (2020) Study of Talpona River Mouth by using Geospatial Technology, Studies in Indian Place Names 40 (50), 791-800.

[32]. Salunke V. S., Kudnar N. S. et al., (2020) Application of Geographic Information System (GIS) for Demographic Approach of Sex Ratio in Maharashtra State, India, International Journal for Research in Applied Science \& Engineering Technology (IJRASET), Volume 8 Issue XI, pp-259-275

[33]. Salunke V. S., Bhagat R. S. et al., (2020) Geography of Maharashtra, Prashant Publication, Jalgaon, pp- 1-229.

[34] . Salunke V. S., (2020) Geographical analysis of scheduled tribe's population in Ahmednagar district, Maharashtra Bhugolshastra Sanshodhan Patrika 37 (1), 52-56.

[35]. Saufi A, O'Brien D, Wilkins H (2014) Inhibitors to host community participation in sustainable tourism development in developing countries. J Sustain Tour 22(5):801-820. doi:10.1080/09669582.2013.861468

[36]. Turton SM (2005) Managing Environmental impacts of recreation and tourism in rainforests of the wet tropics of Queensland world heritage area. Geographical Research 43(2): 140-151. https://doi.org/10.1111/j.17455871.2005.00309.x

[37]. Wang, D., Niu, Y., Sun, F. et al.(2017) Evolution and spatial characteristics of tourism field strength of cities linked by high-speed rail (HSR) network in China. J. Geogr. Sci. 27, 835856. https://doi.org/10.1007/s11442-017-1409-1

[38]. Witt, S., \& Martin, C. (1989) Demand forecasting in tourism and recreation. In C. P. Cooper (Ed.), Progress in tourism and recreation and hospitality management (pp. 433). London: Belhaven.

[39]. Yang Q Meng J, Wang X (2015) Space differential evaluation and promotion strategy of ecotourism carrying capacity of upper reaches of Lijiang River based on the multilevel state space approach. Acta Scientiarum Naturalium Universitatis Pekinensis 51(1): 131-140. (In Chinese) https://doi.org/10.13209/j.0479-8023.2014.162

[40]. Zhang M, Zhao KT, Fang HL (2005) Tourist resources in Linzhi Regions of Tibet and its exploita and utilization. Journal of Northeast Forestry University 33(3): 80-82. (In Chinese).

\section{Cite this article as :}

Vasudev S. Salunke, Santosh J. Lagad, Ravindra S. Bhagat, Nanabhau S. Kudnar, "A Geospatial Approach to Enhance Point of the Interest and Tourism Potential Centers in Parner Tehsil in Maharashtra, India", International Journal of Scientific Research in Science, Engineering and Technology (IJSRSET), Online ISSN : 2394-4099, Print ISSN : 2395-1990, Volume 8 Issue 1, pp. 186-196, January-February 2021. Available at

doi : https://doi.org/10.32628/IJSRSET218136 Journal URL : https://ijsrset.com/IJSRSET218136 